\title{
Chronic effects of dredging-induced stress on the clam (Spisula solida): nucleic acid and lipid composition
}

\author{
Maria A. Chícharo ${ }^{\mathrm{a}, *}$, Luis Chícharo $^{\mathrm{b}}$, Ana Amaral ${ }^{\mathrm{a}}$, \\ Sílvia Condinho ${ }^{\mathrm{a}}$, Miguel Gaspar ${ }^{\mathrm{b}}$ \\ ${ }^{a}$ Universidade do Algarve, CCMAR, FCMA, Campus de Gambelas, 8000 Faro, Portugal \\ ${ }^{\mathrm{b}}$ Instituto de Português de Investigação das Pescas e do Mar, CRIP sul-8700 Olhão, Portugal \\ Received 7 August 2002; received in revised form 4 February 2003; accepted 26 February 2003
}

\section{Abstract}

Responses of the clam Spisula solida to stress imposed by dredging were analyzed in terms of changes in chronic indices of biochemical conditions (RNA/DNA ratio and neutral/polar (N/P) lipid ratio). Cumulative stress on undersized $(<25 \mathrm{~mm})$ S. solida from repeated habitat disturbance by dredging was simulated in the laboratory and measured with in situ studies off the southern coast of Portugal, in April and July 1999. Laboratory simulations on undersized bivalves indicated decreases in RNA/DNA and N/P lipid ratios. Responses were sublethal; however, even though survival was not directly threatened, decreases in condition suggest that bivalves are more susceptible to predation when they have been left in the seabed after the dredging activity. Moreover, the in situ study revealed that this effect could be especially critical during spawning.

(C) 2003 Published by Elsevier Science B.V.

Keywords: Spisula solida; Dredging; Sublethal effects; Biochemical indices

\section{Introduction}

There are several sandy fishing grounds off the Algarve coast of Portugal where bivalves can be harvested. In these areas clams are caught with dredges, which act as a rake when the dredge is dragged through the sediment. The effects of shellfish dredging on ecosystem are well described (Maltby, 1999; Chícharo et al., 2002), but the physiological effects have received little attention (Maguire et al., 1999a,b, 2002a,b). Despite the high efficiency of the Portuguese clam dredge, clams not captured may die as a consequence of fishing. In Portugal, bivalves are

\footnotetext{
* Corresponding author. Tel.: +351-289-800900; fax: +351-289-818353.

E-mail address: mchichar@ualg.pt (M.A. Chícharo).
}

subjected to successive habitat disturbance by dredg- 34 ing. Undersized bivalves (those that can pass through 35 the mesh of the dredge), which for Spisula solida are 36 individuals less than $25 \mathrm{~mm}$ long, are especially af- 37 fected. The passage of fishing gear across the seabed 38 leads to both direct and indirect mortality through 39 subsequent predation (Kaiser and Spencer, 1995). 40

Dredge fishing is known to affect various phys- 41 iological/biochemical processes associated with or- 42 ganism metabolism (Maltby, 1999). Knowledge of 43 organism-level responses to dredge-induced stress is 44 essential for understanding its adverse effects and 45 the strategies adopted by organisms to tolerate such 46 stress.

The biochemical composition of the animals can reflect the overall conditions of the bivalves' environment. The RNA/DNA ratio is an eco-physiological 
index of activity (growth, reproduction, secretion, etc.) under a given environmental condition (Lucas and Beninger, 1985). RNA/DNA ratios have been used on a wide range of marine organisms, principally fish (Bulow, 1970; Buckley, 1984), crustaceans (Anger and Hirche, 1990), and bivalves (Grémare and Vétion, 1994; Chícharo and Chícharo, 1995; Chícharo et al., 2001). This index is based on the assumption that the amount of DNA, the primary carrier of genetic information, is stable under changing environmental situations within the somatic cells of a species (Clemmesen, 1994), whereas the amount of RNA is known to vary with age, life-stage, organism size, disease-state and with changing environmental conditions (Bulow, 1970). Thus, bivalves in good condition tend to have higher RNA/DNA ratios than do those in poor condition.

Another indicator of physiological condition is the energy storage index, which is the neutral/polar (N/P) lipid ratio proposed by Hentschel (1998). According to this author, quantifying neutral lipids (triglycerides) indicates the degree to which energy gain exceeds energy demand, whereas polar lipids (cholesterol and phospholipids), having a structural function in cell membranes, indicate body size and are less variable.

The aims of this work were to determine (1) changes in different chronic biochemical condition indices (RNA/DNA and N/P lipid ratios) of undersized $(<25 \mathrm{~mm})$ S. solida in response to cumulative stress imposed in a laboratory simulation of dredging activity and (2) in situ seasonal changes in the condition of $S$. solida before and after dredging, according to RNA/DNA and N/P lipid ratios.

\section{Methods}

\subsection{Laboratory experiments}

A simulation of dredging stress on undersized bivalves (i.e. those able to pass through the dredge mesh) was developed under laboratory conditions, with 120 S. solida of less than $25 \mathrm{~mm}$ length being used. The bivalves were maintained for 1 day in oxygenated, filtered seawater and fed with the microalgae Isochrysis sp. $\left(4.27 \times 10^{6}\right.$ cells $\left./ \mathrm{ml}\right)$ before experimentation. To simulate dredging stress, the bivalves were shaken for $3 \mathrm{~min}$ every $30 \mathrm{~min}$ for a $6 \mathrm{~h}$ period. After each shaking, 10 bivalves were removed, measured, weighed, and the foot divided into thirds. Each third was placed in an Eppendorf tube and frozen in liquid nitrogen. Later, each third was analyzed for the N/P lipid and RNA/DNA ratios.

\subsection{Field procedures}

For this study, bivalves were carefully collected in situ by SCUBA divers, from an area that had not been dredged and from three separate dredge tracks generated from normal fishing procedures. Surveys were conducted at the Algarve coast (south Portugal) in Vilamoura area $\left(37^{\circ} 05^{\prime} \mathrm{N}, 8^{\circ} 2^{\prime} \mathrm{W}\right)$, in spring (April) 1999 and summer (July) 1999. For each treatment, we collected 60 bivalves ( 15 per treatment, before and after fishing in spring and summer). After collection, all individuals were immediately frozen and stored in liquid nitrogen, until samples were processed. In the laboratory, the foot of each bivalve was sectioned, and the dry weight determined after lyophilization. Samples were further processed to determine RNA/DNA and N/P lipid ratios.

\subsection{Biochemical procedures}

\subsubsection{Nucleic acids}

Nucleic acids were extracted and purified from bivalve foot tissue homogenates, and fluorescencephotometric measurements were made using ethidium bromide (EB), a specific nucleic acid fluorochrome dye (Chícharo et al., 2001). The fluorescence was determined by exciting at $365 \mathrm{~nm}$ and reading at $590 \mathrm{~nm}$ with a spectrofluorometer (Hitachi model 650-10). RNA fluorescence was calculated as the RNA + DNA fluorescence minus DNA fluorescence after RNase treatment.

\subsubsection{Lipids}

Lipid extraction involved fluorescence-photometric measurements using Nile red (RD), a specific lipid fluorochrome dye (Hentschel, 1998). Both neutral and polar lipids can be quantified simultaneously via spectrofluorometry of the same stained sample: neutral lipids; excitation $488 \mathrm{~nm}$; emission $560 \mathrm{~nm}$; polar lipids; excitation $549 \mathrm{~nm}$; emission $628 \mathrm{~nm}$. 


\subsection{Data analysis}

The homogeneity of variances and normality of data were tested using the Levene's and chi-square tests, respectively. When the ANOVA assumptions were followed, we applied a one-way ANOVA to analyze whether the values were significantly different. Where significant differences were found using the ANOVA, a Tukey test (HSD) was employed. When the ANOVA assumptions were not followed, we applied the Kruskal-Wallis test (non-parametric ANOVA) because the distribution of data was not normal. All statistical analyses were made with the software package STATISTA V.5.

\section{Results}

\subsection{Cumulative stress experiment}

There were significant differences over time in the RNA/DNA ratios in $S$. solida subjected to cumulative stress (Kruskal-Wallis test, $P=0.03$ ), with the condition of the bivalves decreasing during the experiment (Fig. 1). Furthermore, the N/P lipid ratios generally decreased with increasing cumulative stress. A one-way ANOVA test revealed these differ- 159 ences to be significant $\left(F_{(11.48)}=9.62, P<0.001\right) . \quad 160$ The corresponding Tukey (HSD) test revealed that 161 the test at 14:00 h significantly differed from the 162 test at other times, as did the $13: 00 \mathrm{~h}$ test from 163 the $13: 30 \mathrm{~h}$ test, the $15: 00 \mathrm{~h}$ from the $12: 30$ and 164 $13: 30 \mathrm{~h}$, and the $15: 30 \mathrm{~h}$ from the $12: 30$ and $13: 30 \mathrm{~h} \quad 165$ (Fig. 2).

\subsection{In situ study}

Seasonal changes in the RNA/DNA ratio were sig- 168 nificant $(P<0.0001)$ and more obvious than the 169 changes arising through the direct impact of the fishery 170 itself (non-significant results, $P<0.145$ ). Moreover, 171 the condition, as exhibited in the RNA/DNA ratio, of 172 those bivalves collected in April was generally lower 173 than that of individuals collected in July (Fig. 3). Only 174 in April was a decrease in condition after the dredging 175 impact detected.

Seasonal changes in the N/P lipid ratios were signif- 177 icant between spring (April) and summer (July) $(P<178$ 0.0067) (Fig. 4). The condition of the bivalves col- 179 lected in April was lower than that of those collected 180 in July, but no differences were detected before and 181 after the dredging $(P<0.467)$.

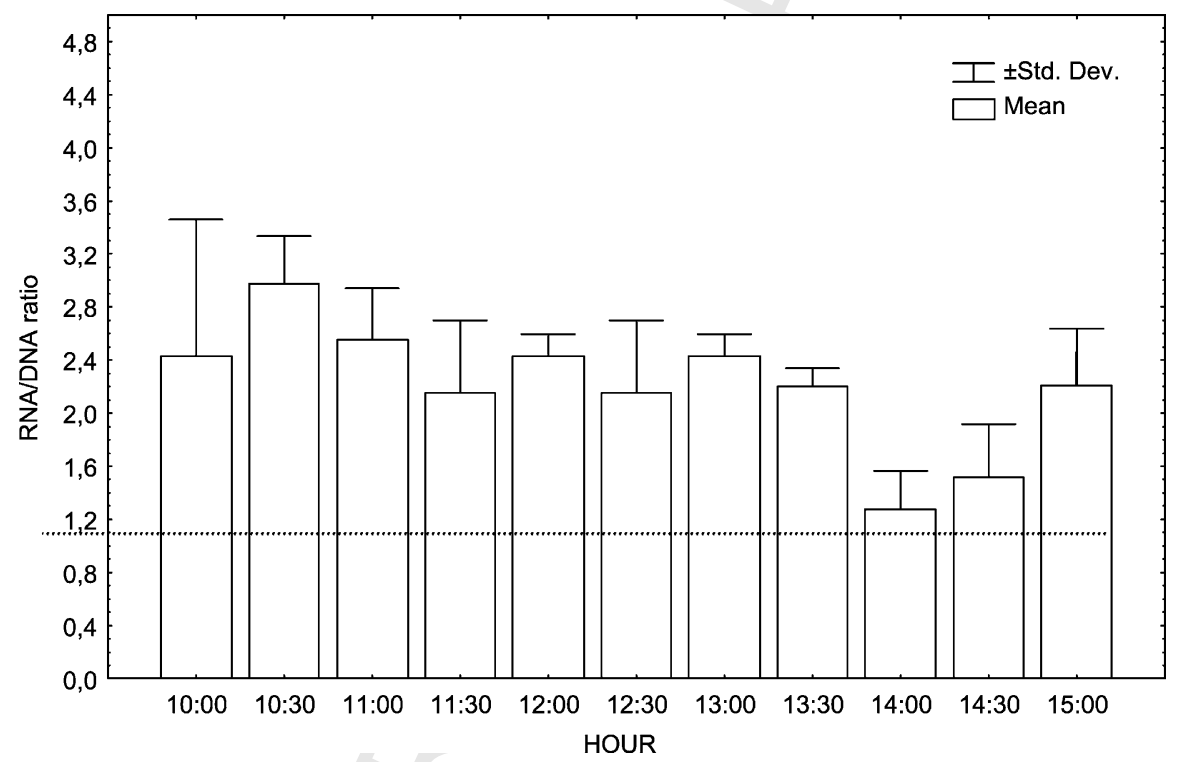

Fig. 1. Comparison of the mean and standard deviation of RNA/DNA ratios between periods of cumulative stress (h) on S. solida. Kruskal-Wallis test: $P=0.03$. The dotted line represents the critical level. 


\section{ARTICLE IN PRESS}

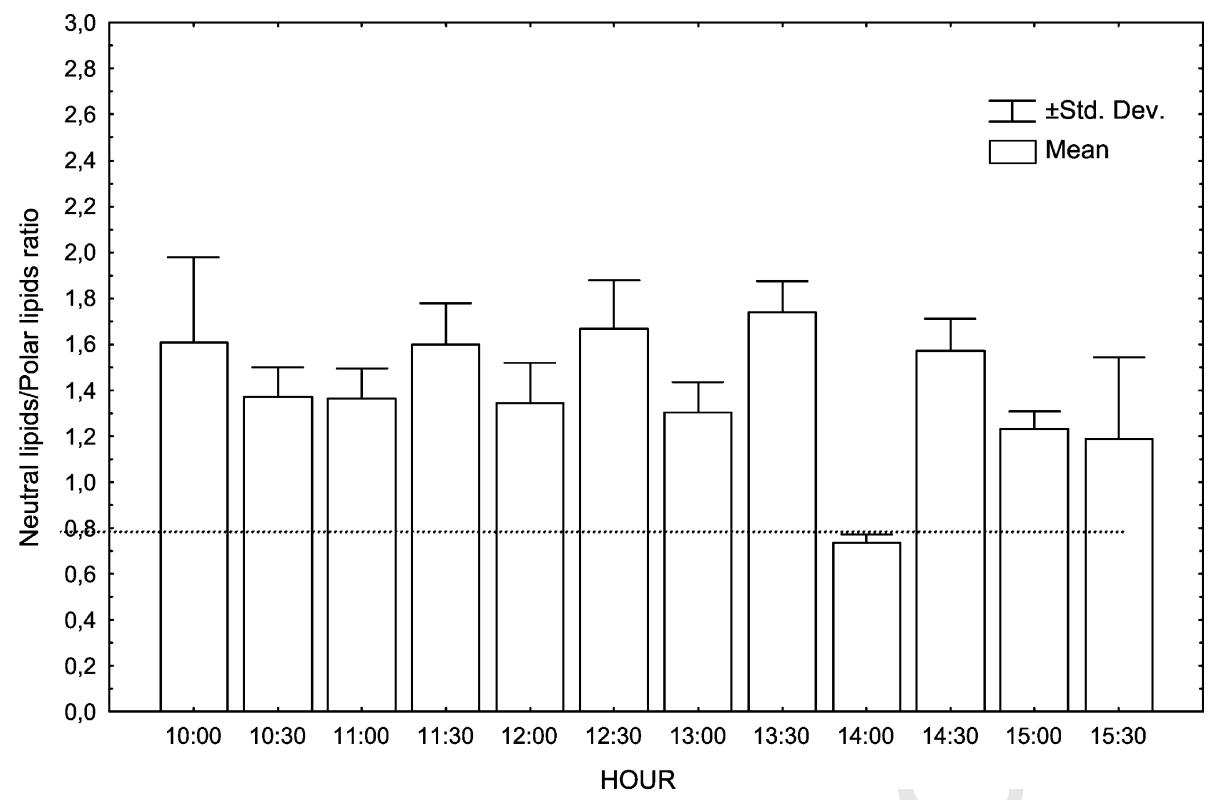

Fig. 2. Comparison of the mean and standard deviation of N/P lipid ratios between $S$. solida exposed to different levels of cumulative stress (h) $\left(F_{(11.48)}=9.62, P<0.001\right.$; Tukey (HSD) test revealed significant differences between 14:00 $\mathrm{h}$ and all the other hours). The dotted line represents the critical ratio for survival.

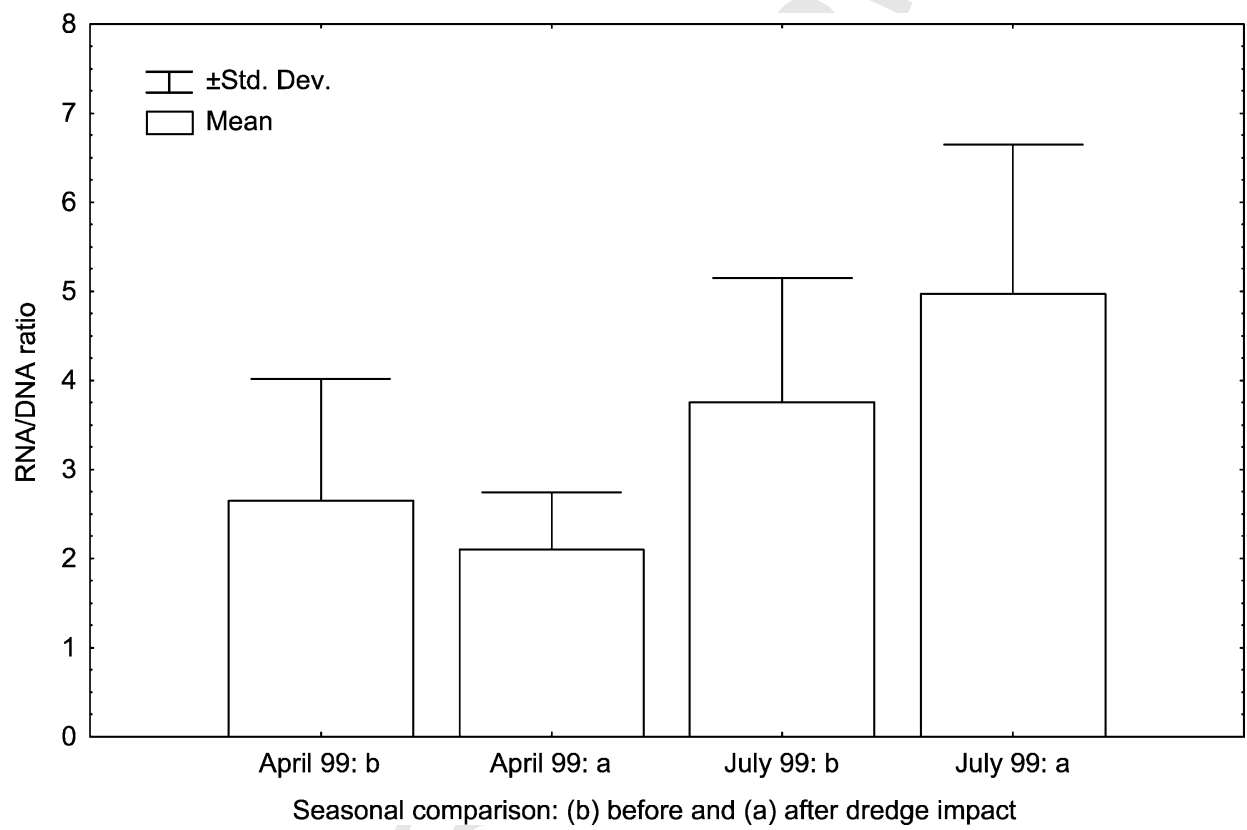

Fig. 3. Comparison of RNA/DNA ratios in S. solida collected at a fishing ground, before and after dredging, with corresponding means and standard deviations (month main effect: $F_{(3.36)}=9.17, P<0.0001$; Tukey HSD revealed significant differences between April and July). 


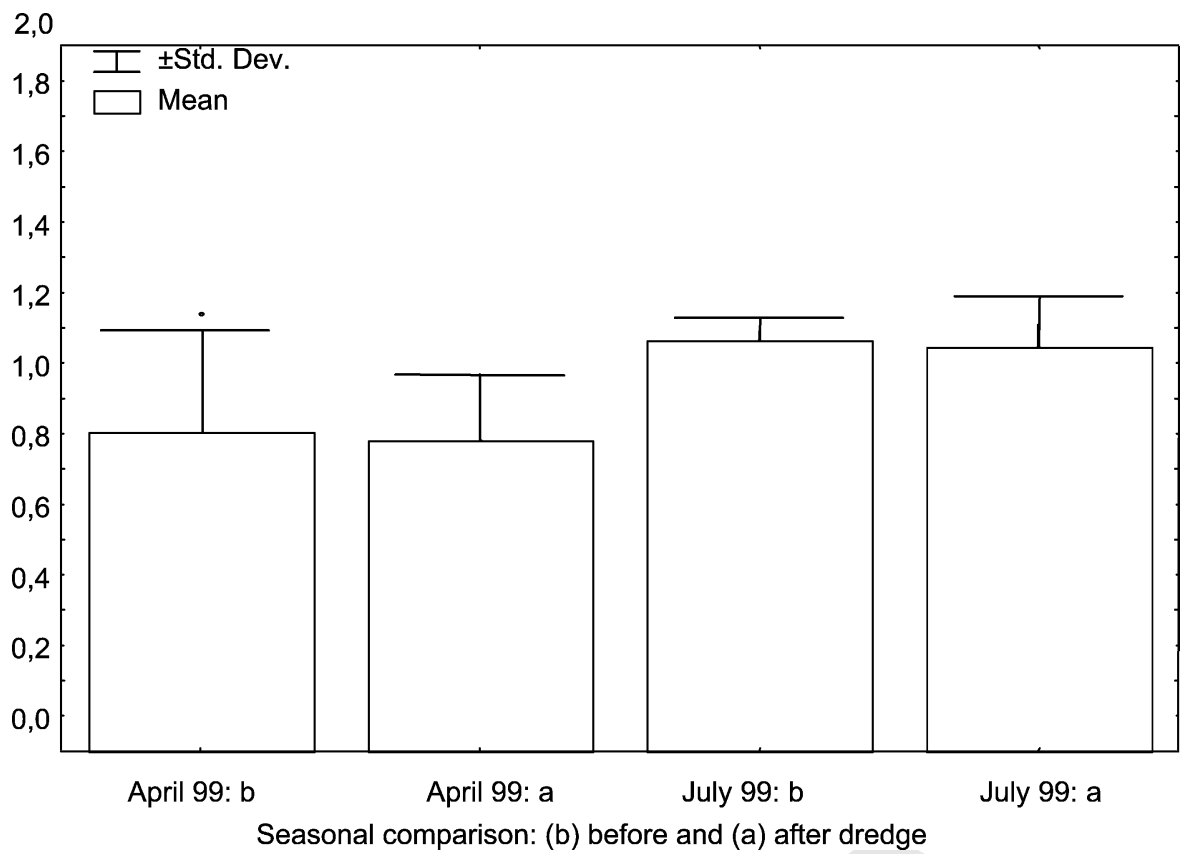

Fig. 4. Comparisons of N/P lipid ratios in S. solida collected at a fishing ground, before and after dredging, with corresponding means and standard deviations (month main effect: $F_{(3.32)}=5.87, P<0.0067$; Tukey HSD revealed significant differences between April and July).

\section{Discussion}

To assess the impact of dredging on field-caught bivalves it is necessary to establish the threshold level of the biochemical indicator being used; i.e. the level below which the organism would be classified as severe stressed, which implies its minimal survival condition, i.e. the critical level.

A few studies have determined critical levels for bivalves. Chícharo and Chícharo (1995) established that, among Ruditapes decussatus in Ria Formosa (Portugal), survival was not guaranteed when the RNA/DNA ratio was lower than 1 . The minimum ratio of N/P lipids described here is in accordance with previous studies of polychaetes by Hentschel (1998), who suggested that a critical level of 0.8 corresponded to an organism in low condition. When this level was reached, almost all lipid reserves were used. Because of the absence of such values for $S$. solida, we have assumed the last critical values for this species.

In the field, there was at least one type of stress imposed on the undersized bivalves, viz. the cumulative mechanical stress due to successive disturbances from dredging in the same area. The results of N/P lipid 205 ratios and RNA/DNA ratios of laboratory-stressed bi- 206 valves indicated that both indices decreased after the 207 bivalves were shaken in the simulation of the stress that 208 undersized bivalves experience from repeated dredg- 209 ing in the same area. However, critical ratios were 210 reached only occasionally. We therefore reject the hy- 211 pothesis of an intense decrease in RNA concentration 212 as a response to increased stress. This rejection is also 213 based on the findings of Clemmesen (1994), where a 214 sudden increase in stress leads first to decreased ribo- 215 some activity followed by a decrease in ribosome num- 216 bers, and on the fact that fluorometric methods mea- 217 sure only the ribosome content. A similar explanation 218 seems to apply to the lipid index, in that stress applied 219 for a few hours does not lead to an intense degrada- 220 tion of lipid reserves that allow the minimum ratio to 221 be achieved. In fact, except at 14:00 h, the minimum 222 ratio for survival was not reached during this exper- 223 iment. Therefore, both these indices show the tested 224 dredging effects are sublethal. 225

Normal seasonal differences were invariably higher 226 than the recorded stress-induced changes. These re- 227 
sults are to be expected, as the biochemical indices test chronic stress only. RNA/DNA and N/P lipid ratios indicate lower bivalve condition in April. This decline is the result of spawning activity. Spawning in $S$. solida along the south coast of Portugal occurs from February to May, with the greatest spawning activity occurring in April (Gaspar, 1996). Cockles and clams lose condition during the spawning season (Boyden, 1971). This loss of condition would be especially evident through analysis of muscle tissue, as in this study, because during spawning proteins and lipids from muscle are redirected towards gonad development (Paon and Kenchington, 1995). Increased values of RNA/DNA and N/P lipid ratios were recorded in July, 3 months after spawning, which indicates that the bivalves had recovered from the intense physiological activity of gamete production. Nevertheless, even if survival is not directly threatened by dredging, a decrease in condition during the spawning season, especially if indicated by a fall in the RNA/DNA ratio, can imply that bivalves are more susceptible to predation after being left on the seabed. Further studies should examine the effects of dredging stress on acute stress indicators because the stress effect should be greater than those detected in the present study.

\section{Acknowledgements}

This study was supported by the FAIR ECODREDGE (PL-4465) Project. Thanks are also due to the EcoResources Group for help with the processing of laboratory samples, and to the staff of the research vessel, "Donax", from IPIMAR.

\section{References}

Anger, K., Hirche, H.J., 1990. Nucleic acids and growth of larvae and juvenile spidercrab, Hyas araneus. Mar. Biol. 705, 403411.

Boyden, C.R., 1971. A comparative study of the reproductive cycles of the cockles Cerastoderme edule and C. glaucum. J. Mar. Biol. Assoc. UK 51, 605-622.

Buckley, L., 1984. RNA/DNA ratio: an index of larval fish growth in the sea. Mar. Biol. 80, 291-298.
Bulow, J.F., 1970. RNA-DNA ratios as indicators of recent growth 269 rates of fish. J. Fish. Res. Bd. Canada 27, 2343-2349. 270

Chícharo, L., Chícharo, M.A., 1995. The RNA/DNA ratio as useful 271 indicator of the nutritional condition in juveniles of Ruditapes 272 decussatus. Scientia Marina 59 (Suppl. 1), 95-101. 273

Chícharo, L., Chícharo, M.A., Alves, F., Amaral, A., Pereira, 274 A., Regala, J., 2001. Diel variation of the RNA/DNA ratios 275 in Crassostrea angulata (Lamarck) and Ruditapes decussatus 276 (Linnaeus 1758) (Mollusca, Bivalvia). J. Exp. Mar. Biol. Ecol. 277 259 (1), 121-129.

Chícharo, L., Regala, J., Gaspar, M., Alves, F., Chícharo, M.A., 279 2002. Macrofauna spatial differences within clam dredge-tracks 280 and their implications for short-term fishing effects studies. 281 Fish. Res. 54 (3), 349-353.

Clemmesen, C., 1994. The effect of food availability, age or size 283 on the RNA/DNA of individually measured herring larvae: 284 laboratory calibration. Mar. Biol. 118, 377-382. 285

Gaspar, M.B., 1996. Bivalves do litoral oceânico algarvio. Aspectos 286 da biologia, ecologia e da pescaria dos mananciais de interesse 287 económico: aplicação à gestão dos recursos (Bivalves of the 288 Algarve coast. Biology aspects, ecology and fisheries of the 289 commercial stocks: application to the resource management). 290 Ph.D. Thesis. Universidade do Algarve, Faro, Portugal, 317 pp. 291

Grémare, A., Vétion, G., 1994. Comparison of several spectrofluo- 292 rometric methods for measuring RNA and DNA concentrations 293 in the deposit-feeding bivalve Abra ovata. Comp. Biochem. 294 Physiol. 107 (2), 297-308.

Hentschel, B.T., 1998. Spectrofluorometric quantification of neutral 296 and polar lipids suggested a food-related recruitment bottleneck 297 for juveniles of a deposit-feeding polychaete population. 298 Limnol. Oceanogr. 43 (3), 543-549. 299

Kaiser, M.J., Spencer, B.E., 1995. Survival of by-catch from a 300 beam trawl. Mar. Ecol. Prog. Ser. 126 (1-3), 31-38. 301

Lucas, A., Beninger, P.G., 1985. The use of physiological condition 302 indices in marine bivalve aquaculture. Aquaculture 44, 187- 303 200.

Maguire, J.A., Fleury, P.G., Burnell, G.M., 1999a. Some methods 305 for quantifying quality in the scallop Pecten maximus (L.). J. 306 Shell. Res. 18 (1), 59-66. 307

Maguire, J.A., O'Connor, D.A., Burnell, G.M., 1999b. An 308 investigation into behavioural indicators of stress in juvenile 309 scallops. Aquacult. Int. 7, 169-177.

Maguire, J.A., Jenkins, S., Burnell, G.M., 2002a. Effects of 311 dredging on undersized scallops. Fish. Res. 56 (2), 155-165. 312

Maguire, J.A., Coleman, A., Jenkins, S., Brand, A., Burnell, G.M., 313 2002b. Temporal and spatial variability in dredging induced 314 stress in the great scallop Pecten maximus (L.). J. Shell. Res. 315 21 (2), 81-86.

Maltby, L., 1999. Studying stress: the importance of organism-level 317 responses. Ecol. Appl.: Ecol. Appl. 9 (2), 431-440. 318

Paon, L.A., Kenchington, E.L.R., 1995. Changes in somatic and 319 reproductive tissues during artificial conditioning of the sea 320 scallop, Placopecten magellanicus (Gmelin, 1791). J. Shell. 321 Res. 14 (1), 53-58. 